\title{
INDONESIA UNTUK KEADILAN (APIK) BANTEN DALAM MEMBERIKAN PERLINDUNGAN HUKUM BAGI MASYARAKAT
}

\author{
Lili Rubin', Ikman Nur Rahman², Qotrun Nida ${ }^{3}$ \\ Dosen Program Studi PPKn FKIP Universitas Sultan Ageng Tirtayasa \\ Serang, Indonesia \\ lilirubin@gmail.com ${ }^{1}$, ikman_rahman@untirta.ac.id ${ }^{2}$
}

\begin{abstract}
This study aims to describe how the role of LBH APIK Banten in providing legal protection for the society. Qualitative descriptive was used in this study. A Director, an Advocate, Management of LBH APIK Banten, and society who had been assisted in handling their cases by LBH APIK Banten were employed as the subjects of this research. Interviews, an observation, and documentation were used as data collection technique. Data reduction, data presentation, and drawing conclusions were employed to analyze the data of this research. Data validity was done by technical triangulation, source triangulation, and member check. The results revealed that there was an active role from LBH APIK Banten in providing legal protection for the society including public services, social education, orderly legal improvement, and legal reform. So far, LBH APIK Banten has been provided legal protection for society who had violence against women and children by helping and handling their cases until they got a verdict. In carrying out its role in providing legal protection to underprivileged people, there were obstacles definitely, where the cases handled by LBH APIK Banten were specific such a handling special cases of violence against women and children who had domestic violence, sexual harassment, abuse, rape, and children abuse. Surely, it was rarely reported by someone who had violence such as abuse, rape, domestic violence, etc in Banten. Therefore, there were slightly cases handled by LBH APIK because of the limited disposition of LBH APIK that handling specific cases of women and children then the lack of Human Resources and funds until very slightly in doing an activity, hampered by Legal Enforcement Officials (APH) and the lack of openness' client in telling the cases' chronology to the LBH APIK Banten.
\end{abstract}

Keywords : Legal Protection for the society

\section{PENDAHULUAN}

Lembaga Bantuan Hukum (LBH) merupakan suatu lembaga bantuan hukum yang memiliki garis koordinasi di bawah Kementerian Hukum dan Hak Asasi Manusia (Kemenkumham) yang berperan sebagai lembaga yang bersifat non profit serta memiliki fungsi sebagai pemberi bantuan hukum pada masyarakat, dalam hal memberikan pendampingan di ruang lingkup seperti (peradilan agama, peradilan militer dan peradilan tata usaha negara
(PTUN) dan juga memberikan penyuluhan hukum pada masyarakat. Lembaga Bantuan Hukum juga melakukan pendampingan hukum pada masyarakat yang mengalami kasus baik perdata, maupun pidana yaitu untuk membantu masyarakat yang kurang mampu baik dalam hal ekonomi untuk membantu masyarakat memperoleh kehadilan di hadapan hukum. Dari hasil pra penelitian dengan mewawancari advokat dari LBH APIK Banten, kasus yang saat ini sering terjadi di Kota Serang yaitu mengenai 
kasus kekerasan terhadap perempuan dan anak. kasus tersebut semakin marak terjadi di dalam masyarakat sekitar, diantaranya meliputi Kekerasan Dalam Rumah Tangga, (KDRT), pemerkosaan, penelataran anak, kekerasan terhadap anak, pelecahan seksual di bawah umur dan perceraian. Terlebih kekerasan seksual yaitu pemerkosaan yang dialami seorang perempuan dan anak. Pelecehan seksual yang di lakukan terhadap perempuan dan anak merupakan bentuk perbuatan yang bertentangan dengan sisi kemanusiaan. Dengan adanya kasus kekerasan pada perempuan dan anak maka didirikan suatu Lembaga Bantuan Hukum (LBH) Asosiasi Perempuan Indonesia untuk Keadilan (APIK) Banten didirikan khusus untuk perempuan dan anak yang buta terhadap hukum dan menjadi korban tindak pidana kekerasan. Dengan adanya LBH APIK Banten sebagai bukti kesadaran perempuan untuk mempertahankan haknya. Dengan begitu setiap perempuan yang menjadi korban tindak pidana kekerasan dapat melaporkan kasusnya pada LBH APIK yang telah didirikan oleh para perempuan yang berinsiatif menegakkan hak-hak korban terlebih pada perempuan dan anak. masyarakat Kota Serang tentang adanya LBH APIK Banten tentu sangat membantu bagi masyarakat sekitar. Tingkat kepuasan masyarakat terhadap LBH APIK
Banten tentunya sangat puas dapat membantu menangani kasus Kekerasan Dalam Rumah Tangga (KDRT), pelecehan seksual, penganiyayaan, pemerkosaan dan pelantaran anak yang di alami oleh sebagian masyarakat. LBH APIK Banten dalam menangani kasus itu lebih fokus pada perempuan dan anak (laki-laki dan perempuan). Dari hasil pra penelitian $\mathrm{LBH}$ APIK Banten ini telah berdiri dari tahun 2010 dan LBH APIK ini bediri di beragai provinsi yang ada di Indonesia. Namun, belum tersebar secara keseluruhan di tiaptiap provinsi. Serta LBH APIK Banten ini bersifat non profit artinya LBH APIK Banten ini gratis bagi masyarakat yang kurang mampu yang terkena masalah atau kasus kekerasan pada perempuan dan anak. Mayoritas yang datang ke LBH APIK Banten ini orang yang tidak mampu dalam menangani masalah atau kasus. LBH APIK Banten ini lebih pada kasus atau permasalahan mengenai Kekerasan Dalam Rumah Tangga (KDRT), pelecehan seksual, pemerkosaan, penelantaran anak, pencabulan, penganiyayaan dan kekerasan pada anak. Dalam menangani kasus selama ini yang paling sering yaitu kasus pelecehan seksual pada perempuan dan anak. LBH APIK Banten tidak ingin menangani kasus perempuan dan anak yang berkaitan dengan narkoba. Hal tersebut dikarena dinilai 
masalahnya sangat sulit sehingga $\mathrm{LBH}$ APIK Banten hanya terfokus pada masalah kekerasan pada perempuan dan anak saja.

Berdasarkan data yang didapatkan peneliti pada saat melakukan penelitian di $\mathrm{LBH}$ APIK Banten, jumlah tindakan kekerasan pada perempuan dan anak yang terjadi di kota serang, hampir setiap tahun terjadi baik kasus KDRT, pelantaran anak, pemerkosaan, penganiyayaan dan pelecehan seksual di bawah umur. Berikut data kasus di Kota Serang dari Tahun 2014-2018 :

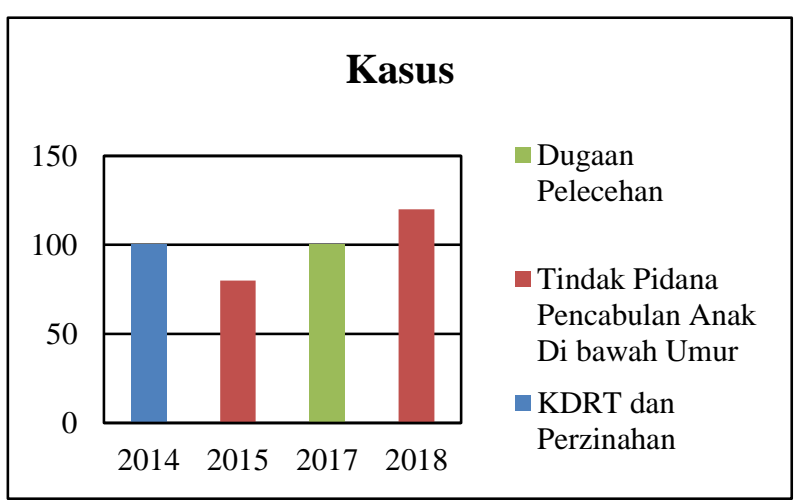

Sumber : (LBH APIK Banten) dari tahun 2014-2018

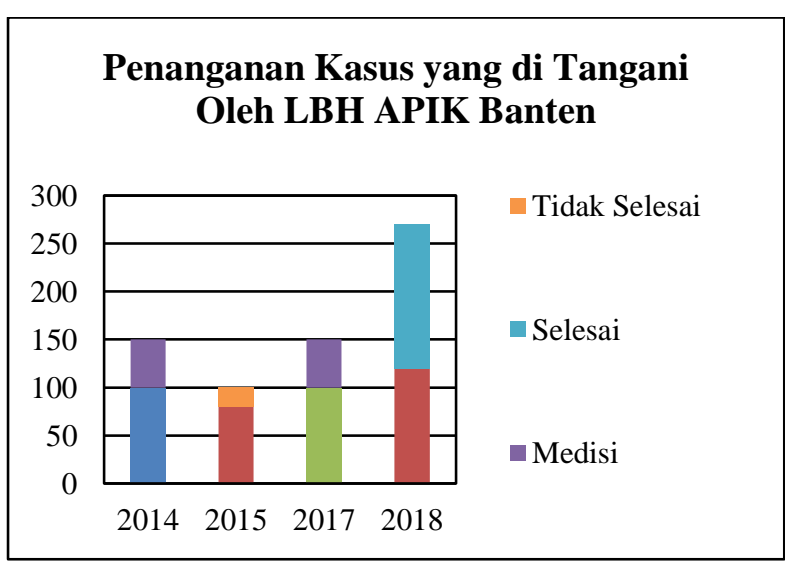

Sumber : (LBH APIK Banten) dari tahun 2014-2018

Berdasarkan tabel diatas dapat disimpulkan kasus di LBH APIK Banten hampir setiap tahunnya terjadi kasus pada perempuan dan anak diantaranya yaitu pada tahun 2014 terjadi kasus KDRT dan Perzinahan, tahun 2015 terjadi kasus Tindak pidana pencabulan anak di bawah umur, kemudian pada tahun 2017 tejadi kasus dugaan pelecehan, dan pada tahun 2018 terjadi kasus yang sama yaitu tindak pidana pencabulan anak di bawah umur.

Dari beberapa kasus yang di paparkan tersebut bahwa kasus yang di tangani oleh LBH APIK Banten pada tahun 2014 mengenai kasus KDRT dan perzinahan dalam penanganan yang di lakukan oleh LBH APIK Banten dalam kasus ini selesai, pada tahun 2015 pada kasus tindak pidana pencabulan anak dibawah umur dalam penanagan kasus tersebut tidak selesai di tangani oleh LBH APIK Banten, dikarenakan tersangka kabur hingga saat ini belum di temukan oleh pihak kepolisisan, kemudian pada tahun 2017 terjadi kasus dugaan pelecehan dimana dalam penanganan kasus tersebut yang di lakukan oleh LBH APIK Banten selesai namun dengan cara mediasi antara korban dan tersangka, dan pada tahun 2018 kasus tindak pidana dan kekerasan terjadi lagi pada tahun 2018, dimana pada penanganan kasus ini yang di lakukan oleh LBH APIK Banten telah selesai. Oleh karena itu menarik untuk dikaji bagaimana peran Lembaga Bantuan Hukum (LBH) Asosiasi Perempuan Indonesia Untuk Keadilan (APIK) Banten 
dalam memberikan perlindungan hukum bagi masyarakat.

\section{METODE PENELITIAN}

\section{Tempat Penelitian}

Penelitian dilaksanakan pada bulan Maret sampai dengan Juni 2019 dan mengambil tempat penelitian di lakukan di kantor LBH APIK Banten. Jl. K.H Abdul Fatah Hasan Ciceri Serang Banten, Sumurpecung, Kecamatan Serang, Provinsi Banten. Alasan peneliti melakukan penelitian di LBH APIK Banten tersebut karena LBH APIK Banten merupakan LBH satu-satunya yang ada di provinsi Banten yang khusus menanagani kekerasan terhadap perempuan dan anak sehingga menarik untuk peneliti melakukan penelitian di LBH APIK Banten tersebut.

\section{Metode Penelitian}

Dalam penelitian ini pendekatan yang digunakan oleh peneliti adalah pendekatan kualitatif dengan menggunakan metode deskriptif. Pendekatan penenlitian kualitatif merupakan tahapan dalam penelitian yang menghasilkan data deskriptif yang berupa kata tertulis ataupun lisan dari sumber data atau narasumber serta tingka hlaku seseorang yang dapat diamati dan kemudian dianalisis serta di pandukan dengan berpatokan pada indikator-indikator yang menjadi pedoman dalam penelitiaan ini.
Adapun alasan peneliti meggunakan pendekatan kualitatif yaitu karena dalam penelitian ini tentunya membutuhkan informasi yang mendalam dari informan atau narasumber. Sehingga, dapat memahami makna di balik data dengan melihat secara mendalam mengenai gejala sosial yang terjadi. Peneliti juga ingin mendapatkan temuan-temuan masalah yang mendalam serta informan dapat menjelaskan yang di alami subjek penelitian dalam hal ini peneliti bertujuan untuk mendapatkan data ataupun dapat menjelaskan mengenai peran LBH APIK Banten dalam memberikan perlindungan hukum bagi masyarakat.

Dalam penelitian ini peneliti mengguanakan metode deskriptif Adapun alasan peneliti menggunakan metode deskriptif yaitu dikarenakan peneliti ingin menggambar kan dan menjelaskan apa adanya sesuai dengan kejadian yang berlangsung atau sebaliknya. Sehingga data yang di dapat alamiah serta penelitian ini di dasarkan pada pemecahan masalah yang berdasarkan pada fakta dan kenyataan yang ada pada sekarang, dan juga memfokuskan masalah yang terjadi pada saat penelitian di lakasanakan.

\section{Prosedur Pengumpulan Data}

Prosedur pengumpulan data diartikan sebagai cara atau teknik yang digunakan 
untuk memperoleh data. Di karenakan data sangat dibutuhkan dalam suatu penelitian serta data tersebut akan dipakai dalam pembuktian kebenaran. Adapun teknik yang digunakan untuk mengumpulkan data pada penelitian ini yaitu dengan wawancara, observasi, dan dokumentasi.

\section{Wawancara}

Wawancara merupakan proses dialog atau proses pertukaran informasi antara peneliti sebagai pewawancara dengan informasi sebagai terwawancara. Dalam proses dialog, peneliti memberikan pertanyan kepada informan (narasumber) mengenai permasala han penelitian dan hasil dari dialog tersebut disusun dalam bentuk berupa kata-kata. Dalam penelitian ini peneliti akan menggunakan Wawancara Semiterstruktur (Semistructure Interview). Wawancara semiterstruktur merupakan teknik pengumpulan data yaitu dengan cara merencanakan dan memepersiapkan pedoman wawancara yang berisikan pertanyaan-pertanyan dimana peneliti tidak memepersiapakan jawaban yang akan di taanyakan pada informan, adapun jawaban dari informaan berupa pandangan dan solusi ataupun harapan dari informan. Adapun dalam penelitan ini peneliti memilih wawancara semiterstruktur karena dengan memakai wawancara semiterstruktur ini agar peneliti mendapatkan informasi yang lebih mendalam serta untuk menemukan suatu permasalahan yang di alami secara lebih terbuka. Peneliti menggunakan wawancara semiterstruktur yaitu untuk memberikan kemudahan pada informan atau narasumber dalam menjawabnya mengenai peran dari LBH APIK Banten dalam memberikan perlindungan hukum bagi masyarakat. Dalam melakukan wawancara, peneliti tentunya perlu mendengarkan secara teliti dan mencatat hal-hal yang dikemukan oleh informan. Dengan narasumber atau informan dari LBH APIK Banten yaitu Ketua, Seketaris, Anggota dan Masyarakat yang pernah dibantu oleh LBH APIK Banten.

2. Observasi

Observasi merupakan suatu proses dimana peneliti melakukan terjun langsung ke lokasi (tempat penelitian) atau ke lapangan untuk mendapatkan data serta informasi yang ada di lapangan sebanyak mungkin. Dengan melakukan observasi peneliti kemungkinan melakukan penemuan baru pada saat melakukan observasi dan peneliti dalam melakukan observasi tentunya dapat menemukan hal-hal diluar persepsi dari responden dan juga peneliti dapat memahami dan merasakan mengenai situasi sosial yang di teliti.

Adapun dalam melakukan penelitian ini, Peneliti akan menggunakan observasi terus 
terang atau tersamar. Adapun alasan peneliti memilih observasi terus terang dan tersamar karena peneliti akan melakukan penelitian pada suatu lembaga. Untuk itu dalam melakukan penelitian pada lembaga dan juga untuk melakukan pengumpulan data tentunya peneliti saat datang ke lembaga tersebut peneliti menyatakan secara terus terang jika ingin melakukan penelitian terhadap lembaga tersebut. Dimana lembaga tersebut LBH APIK Banten di Kota Serang. Dalam melakukan observasi ini peneliti memiliki kesempatan untuk mengumpulkan data dari LBH APIK Banten secara mendalam. Sehingga data yang di perlukan oleh peneliti dappat terkumpul secara meneyeluruh. Adapun observasi yang dilakukan oleh peneliti yaitu dengan melalui suatu pengamatan langsung terhadap LBH APIK Banten yang ingin di teliti oleh peneliti, yang berkaitan dengan peran LBH APIK Banten dalam memberikan perlindungan hukum bagi masyarakat.

\section{Dokumentasi}

Dokumen merupakan suatu bentuk yang dapat berupa gambar, film, record dan file yang di tulis oleh seseorang. Dalam penelitian ini dokumentasi yang digunakan berbentuk foto kegiatan wawancara, dan foto pelaksanaan kegiatan LBH APIK Banten.

\section{TEMUAN PENELITIAN}

\section{Peran Lembaga Bantuan Hukum} (LBH) Asosiasi Perempuan Indonesia untuk Keadilan (APIK) Banten Dalam Memberikan Perlindungan Hukum

\section{Bagi Masyarakat}

Berdasarkan hasil wawancara, observasi, dokumentasi mengenai bagaimana peran LBH APIK Banten dalam memberikan bantuan hukum terhadap masyarakat, peneliti mereduksi data yang didapatkan. Menurut Sugiyono (2015:338) reduksi data merupakan merangkum, memilih hal-hal yang pokok, memfokuskan pada hal-hal yang penting, di cari tema dan polannya dan membuang yang tidak perlu. Dengan demikian data yang telah di reduksi akan memberikan gambaran yang jelas dan mempermudah peneliti untuk melakukan pengumpulan data selanjutnya, dan mencarinya bila diperlukan. Dapat diambil kesimpulan bahwa proses reduksi data merupakan suatu proses berupa pemilihan, penyederhanaan, dan adanya transformasi data yang bersifat kasar yang mucul dari catatan-catatan saat peneliti melakukan penelitian dilokasi penelitian.

Adapun, berdasarkan data yang diperoleh melalui hasil wawancara, observasi dan dokumentasi mengenai peran LBH APIK Banten dalam memberikan perlindungan 
hukum bagi masyarakat, peneliti membahas peran LBH APIK Banten berdasarkan empat indikator peran LBH diantaranya public service, social education, perbaikan tertib hukum, dan pembaharuan hukum. Adapun dari keempat indikator tersebut terdapat sub indikator dari masing-masing peran LBH diantaranya sebagai berikut. Peran LBH APIK Banten lainnya yaitu dalam hal public service, dimana berakitan dengan jasa yang diberikan oleh LBH baik berupa pelayanan yang diberikan pada masyarakat atau kliennya. Pada indikator public service ini terdapat lima sub indikator yang terdiri dari Berwujud (Tangible), Keandalan (Reliability), Ketanggapan (Responsiveness), Jaminan (Assurance), dan Empati (Emphaty).

Pada sub indikator pertama yaitu berwujud (Tangible) berdasarkan hasil wawancara menjelaskan bahwa proses pelayanan yang dilakukan oleh LBH APIK Banten dalam melayani kasus klien sangat memudahkan kliennya dan tidak dipersulit sama sekali dalam persyaratannya juga. Bagi masyarakat yang ingin kasusnya dibantu dan di tangani oleh LBH APIK Banten, masyarakat hanya membawa persyaratan berupa foto copy KTP, KK, SKTM dari lurah, kepala desa, atau pejabat yang setingkat ditempat tinggal pemohon bantuan hukum, dan foto copy buku nikah apabila kasusnya berkaitan dengan pernikahan seperti kasus KDRT. Saat melakukan pelayanan klien sangat dimudahkan sekali dan juga tidak dipersulit karena LBH APIK Banten tidak ingin mempersulit kliennya. Apabila klien tidak membawa persyaratan tersebut namun hanya membawa KTP, tetap bisa melakuakan konsultasi. Maka dari LBH APIK Banten sendiri akan memberikan form konsultasi. Setelah klien memenuhi persyaratan-persyaratan maka klien bisa melakukan konsultasi dengan pihak LBH APIK Banten. klien diminta membuat berupa kronologi kasus yang dihadapi oleh klien untuk diserahkan ke pihak LBH dan untuk dipelajari mengenai kasus klien. Setelah semua persyaratan terbilang cukup memenuhi persyaratan, maka klien dapat melakukan konsultasi mengenai kasusnya dengan pihak dari LBH APIK Banten.

Dalam hal ini, berdasarkan hasil wawancara bahwa LBH APIK Banten tentunya benar dalam membantu masyarakat yang kurang mampu dalam memakai jasa pengacara dalam menangani kasus yang berkaitan dengan kasus kekerasan terhadap perempuan dan 
anak baik seperti kasus KDRT, Pelecahan Seksual, Pencabulan Anak di bawah umur dan lain-lain. selain itu juga LBH APIK Banten merespon permasalahan klien dan keluhan yang klien hadapi. Dengan adanya LBH APIK Banten ini tentunya dapat membantu masyarakat.

Adapun berdasarkan hasil wawancara bahwa LBH APIK Banten sudah menjalankan peranya dengan baik dalam membantu masyarakat dan klien yang sedang mengalami kasus kekerasn terhaadap perempuan dan anak yang mengalami tindakan kekerasan seperti (KDRT, Pencabulan anak di bawah umur, Pelecehan Seksual dan Lain-lain). dengan adanya LBH APIK Banten ini sangat membantu masyarakat dan klien dalam menegakkan keadilan. Sebagaimana perannya dalam membantu orang yang tidak mampu baik secara ekonomi serta mewujukan penyamarataan perempuan dan anak. Sejauh ini dari pandnagan masyarakat yang pernah di tangani kasusnya oleh LBH APIK Banten bahwa LBH APIK sudah menjalankan peranya dalam membantu kliennya. Serta LBH APIK sendiri dalam menangani kasus atau permasalah klienya tidak gegabah atau tidak terburu-buru dalam mengambil suatu keputusan. Sehingga dapat memperoleh hasil yang di ingikan dalam kasus tersebut.

Pada sub indikator kedua yaitu keandalan (reliability), dari hasil wawancara menjelaskan bahwa LBH APIK Banten telah memberikan bantuan hukum pada masyarakat dalam menangani kasusnya yang berkaitan dengan kekerasan terhadap perempuan dan anak. Dalam memberikan bantuan hukum pada masyarakat LBH APIK Banten membantu masyarakat dengan semaksimal mungkin dan sesuai dengan prosedur dalam membantu kasus klien yang sedang di hadapi. Serta mengatur strategi untu menangan kasus klien tersebut. Pada sub indikator kedua yaitu ketanggapan (responsiveness), dari hasil wawancara menjelaskan LBH APIK Banten sudah memberikan pelayanan dengan waktu yang tepat. Namun, tergantung dari tingkat ke rumitan kasus tersebut, serta kemauan dari klien dalam kasusnya. Karena ada beberapa dari klien yang mengalami kasus kekerasan terhadap perempuan dan anak. Ada yang ingin kasusnya sampai di ranah mediasi dan ada juga klien ynag ingin kasusnya selesai samapai di tahap persidangan. Jika untuk ke rana mediasi tentunya waktu bisa cepat dan tepat juga. Tetapi jika unuk ranah ke persidangan akan 
membutuhkan waktu yang begitu lama, karena harus mengikuti jadwal persidang yang telah di berikan. Sehingga pihak dari LBH APIK Banten mengikuti kemauan klien. Pada sub indikator kedua yaitu jaminan (Assurance). dari hasil wawancara menjelaskan dalam menangani kasus klien LBH APIK Banten tidak memberikan patokan biaya kepada klien. karena sesuai dengan Undang-Undang No. 16 Tahun 2011 pada Pasal 20 tentang Larangan. Menyatakan bahwa Pemberi Bantuan Hukum dilarang menerima atau meminta pembayaran dari Penerima Bantuan Hukum dan/atau pihak lain yang terkait dengan perkara yang sedang ditangani Pemberi Bantuan Hukum. Tentunya LBH APIK Banten dalam menangani klien tanpa di pungut biaya sepeserpu dan gratis sampai kasus klien selesai. dari hasil wawancara menjelaskan bahwa LBH APIK Banten sudah memberikan perlindungan hukum pada masyarakat yang mengalami tindakkan kekerasan terhadap perempuan dan anak. LBH APIK Bnten memberikan perlindunganya dengan cara membantu masyarakat dalam menangani kasusnya. Dengan adanya LBH APIK Banten ini. Masyarakat tentunya merasa terbantu dan terlindungi dari tindakan kekerasan yang di alami oleh kaum perempuan dan anak. dengan adanya LBH APIK ini masyarakat dapat memperoleh haknya.

Pada sub indikator kedua yaitu Empati (Emphaty). dari hasil wawancara menjelaskan disimpulkan bahwa sejauh ini klien puas terhadap kinerja dari para pengurus LBH APIK Banten dalam menanagani kasus kliennya. Karena kinerja dari LBH APIK Banten yang sesuai dengan prosedur serta tidak gegabah dalam melakukan suatu tindakan pada kliennya. Sehingga memperoleh suatu keputusan yang baik dalam menangani kasusnya. Peran LBH APIK Banten lainnya yaitu Social Education, dimana berkaitan dengan memberikan pemahaman pada masyarakat mengenai bantuan hukum agar masyarakat sadar akan hukum serta hak dan kewajibannya sebagai warga negara. Pada indikator Social Education ini terdapat dua sub indikator yang terdiri dari menyelenggarakan pendekatan atau diskusi langsung kepada masyarakat untuk memberikan pemahaman mengenai hak-hak dan kewajibannya dan bekerjasama dengan pemerintah setempat atau masyarakat setempat untuk melakukan sosialisasi tentang pentingnya hak-hak dan kewajiban. Pada sub indikator pertama yaitu 
menyelenggarakan pendekatan atau diskusi langsung kepada masyarakat untuk memberikan pemahaman mengenai hak-hak dan kewajibannya. Berdasarkan dari hasil wawancara menjelaskan bahwa LBH APIK Banten memberikan pemahaman pada masyarakat mengenai bantuan hukum di lakukan di masyarakat teratai daerah bojonegara, masyarakat petir, dan di lapas perempuan. Selain itu juga LBH APIK Banten sering berkerjasama dengan KEMENKUM HAM.

Pada sub indikator pertama yaitu bekerjasama dengan pemerintah setempat atau masyarakat setempat untuk melakukan sosialisasi tentang pentingnya hak-hak dan kewajiban. Berdasarkan hasil wawancara LBH APIK Banten melakukan kerjasama dengan pemerintah dan masyarakat untuk melakukan sosialisasi berupa pelatihan Paralegal dan BHGS. Pelatihan Paralegal merupakan orang yang sudah terlatih dan mempunyai pengetahuan serta ketrampilan di bidang hukum yang membantu penyelesaian masalah hukum yang dihadapi oleh masyarakat yang mengalami kasus kekerasan terhadap perempuan dan anak. Dengan adanya kegiatan pelatihan paralegal ini menjadi penghubung antara pihak LBH dan masyarakat yang kurang mampu atau miskin di wilayah yang sulit untuk di jangkau oleh pihak LBH APIK. Masayrakat yang mengikuti pelatihan paralegak ini merupakan orang yang mempunyai komitmen untuk membantu dan menyelesaikan masalah hukum yang berkaitan dengan kasus kekerasan terhadap perempuan dan anak. Pelatiha paralegal ini masyarakat diberikan materi berisi hukum dasar dan strategi advokasi. Sehingga mereka dapat menjadi pendamping masyarakat untuk melaporkan kasus yang terjadi di sekitar wilayahnya. Sedangkan jika Bantuan Hukum Gender Struktural (BHGS) merupakan konsep kerja dalam memberikan layanan terhadap korban kekerasan berbasis gender. Dimana BHGS ini menggunakan pengalaman penanganan kasus kekerasan terhadap perempuan untuk melakukan perubahan sistem hukum yang adil dan setara gender. Beberapa kebijakan yang didorong APIK dari BHGS ini, adanay Undang-Undang Nomor 23 tahun 2004 tentang Penghapusan Kekerasan Dalam Rumah Tangga (PKDRT). Kegiatan pelatihan tersebut di ikuti oleh beberapa jaringan dari masyarakat dan beberapa dari pemerintahan. Di antaranya P2TP2A, LSM, Mahasiswa, Pedagang 
Pasar. Dari beberapa jaringan tersebut dalam kegiatan yang di lakukan ini yaitu untuk menyadarakan masyarakat terhadap bantuan hukum dan kesetaraan gender.

Peran LBH APIK Banten lainnya yaitu perbaikan tertib hukum, dimana berkaitan dengan perbaikan hukum dalam bidang peradilan. Pada indikator perbaikan tertib hukum ini terdapat satu sub indikator yaitu membantu masyarakat kurang mampu dalam menyelesaikan permasalahan sampai akhir.

Pada sub indikator ini yaitu membantu masyarakat kurang mampu dalam menyelesaikan permasalahan sampai akhir. Berdasarka dari hasil wawancara menjelaskan bahwa LBH APIK Banten dalam menyelasiakan dan menangani kasus klienya. Tentunya LBH APIK Banten sampai tuntas dalam membantunya. Namun LBH APIK Banten sendiri mengikuti kemaauan dari klien. karena beberapa klien ada yang ingin kasusnya sampai ditahap mediasi dan ada beberapa klien yang ingin sampai ditahap persidangan.

Peran LBH APIK Banten lainnya yaitu pembaharuan hukum, dimana berkaitan dengan peraturan hukum yang sudah ada namun peraturan yang sudah ada tidak dapat memenuhi kebutuhan masyarakat sehingga dibutuhkan suatu pembaharuan hukum yang sesuai dengan kebutuhan masyarakat. Pada indikator pembaharuan hukum ini terdapat sub indikator yang terdiri dari mengusulkan saran terkait peraturan yang dibutuhkan masyarakat.

Pada sub indikator ini yaitu mengusulkan saran terkait peraturan yang dibutuhkan masyarakat. Berdasarkan hasil wawancara bahwa LBH APIK Banten selain menangani kasus klien mengenai kekerasan terhadap perempuan dan anak. adapun LBH APIK Banten melakukan saran terkait kebutuhan yang di butuhkan oleh masyarakat diantaranya mengenai ruang ibu menyusui dan kotak layak anak. LBH APIK mengajukan saran tersebut ke Pemerintah daerah. Dari kedua saran yang diajukan tersebut sudah ada perdanya mengenai kotak layak anak namun untuk saran ruang ibu menyusui perdanya belum ada. LBH APIK Banten melakukan saran tersebut karena dinilai sekarang ini jarang sekali ditemui tempat atau ruang ibu menyusui dan kotak layak anak.

Hal ini sesuai dengan teori yang di kemukakan oleh Dian Permata Sari (2011:26) mengenai peran dan fungsi LBH yaitu public service, sosial education, perbaikan tertib hukum, dan pembaharuan hukum. Adapun pada peran 
LBH APIK Banten dalam memberikan perlindungan hukum bagi masyarakat yaitu setelah peneliti melakukan penelitian melalui wawancara, observasi, dan dokumentasi terkait peran LBH APIK dalam menjalankan perannya sesuai dengan hasil yang didapat bahawa peran LBH APIK Banten sejauh ini sudah menjalankan perannya dengan baik mulai dari melakukan pelayanan pada klien atau masyarakat yang kurang mampu, peranya dalam membantu masyarakat, dan lain-lain. dalam hal ini sesuai dengan peran LBH dalam melayani masyarakat atau kliennya yaitu sesuai dengan Peraturan Pemerintah (PP) Nomor 83 Tahun 2008 tentang Pedoman atau tata cara untuk mendapatkan bantuan hukum. dimana pada pasal (4) dalam Peraturan Pemerintah tersebut dinyatakan untuk memperoleh bantuan hukum bagi masyarakat pencari keadilan mengajukan permohonan tertulis kepada Advokat atau Lembaga Bantuan Hukum. Permohonan meliputi identitas (nama, alamat, dan pekerjaan pemohon) serta uraian singkat mengenai pokok persoalan yang dimohonkan bantuan hukum. Selain permohonan, juga melampirkan SKTM yang dikeluarkan oleh pejabat yang berwenang.
Bagi masyarakat pencari keadilan yang tidak dapat menulis dapat mengajukan permohonan secara lisan yang ditujukan kepada Advokat atau LBH yang selanjutnya dibuatkan secara tertulis kemudian ditanda tangani oleh pemohon dan Advokat atau Lembaga, selanjutnya surat permohonan tersebut dalam waktu 3 (tiga) hari sejak diterima wajib memberikan jawaban serta menunjuk nama-nama Advokat yang akan membantu masyarakat tersebut. Dalam menjalankan perannya sebagai LBH bahwa LBH APIK Banten membantu masyarakat dalam menangani kasus sampai selesai sesuai dengan UndangUndang Republik Indonesia Nomor 16 tahun 2011tentang bantuan hukum pada pasal 4 ayat (3) ruang lingkup menyatakan bahwa Bantuan Hukum sebagaimana dimaksud pada ayat (1) meliputi menjalankan kuasa, mendampingi, mewakili, membela, dan/atau melakukan tindakan hukum lain untuk kepentingan hukum Penerima Bantuan Hukum.

Ada beberapa temuan menarik dalam penelitian ini yaitu berkaitan dengan peran LBH selain menjalankan tugasnya sebagai LBH yang membantu dalam menangani kasus klien selain itu LBH APIK Banten telah melakukan saran 
terkait pertauran yang dibutuhkan oleh masyarakat diantaranya saran yang diajukan ke PEMDA yaitu mengenai ruang atau tempat ibu menyusui dan Kotak Layak Anak (KLA). Adapun dari saran yang telah di ajukan tersebut jika KLA sudah ada perdanya namun untuk ruang ibu menyusui belum terdapat perda.

\section{Cara LBH APIK Banten untuk} mensosialisasikan mengenai bantuan hukum kepada masyarakat.

Cara LBH APIK Banten untuk mensosialisaikan mengenai bantuan hukum kepada masyarakat tentu bukan hal yang mudah bagi LBH APIK Banten. Dalam hal ini dibutuhkan kerjasama antara berbagai pihak yang ada dalam lingkungan masyarakat dan pemerintahan yang terkait dalam memberikan bantan hukum dan perlindungan hukum bagi masyarakat. LBH APIK Banten telah malakukan kegiatan sosialisasi. Berdasarkan hasil wawancara, observasi dan dokumentasi dapat bahwa LBH APIK Banten telah melakukan kegiatan sosialisasi kemasyarakat berupa pemberian penyadaran hukum pada masyarakat dan mengenai BHGS. Adapun bedasarkan hasil wawancara bahwa cara LBH APIK Banten untuk mensosialisasikan mengenai bantuan hukum pada masyarakat yaitu dengan cara melalui diskusi, pelatihan, dan melakukan pelayanan hukum secara langsung pada masyarakat.

3. Kendala yang menghambat peran LBH APIK Banten dalam memberikan bantuan hukum kepada masyarakat.

Dalam memberikan bantuan hukum dan juga perlindungan hukum pada masyarakat pastinya terdapat kendala ataupun hambatan, begitu juga dalm memberikan bantuan hukum terdapat berbagai hambatan yang di hadapi dalam memberikan batuan hukum pada masyarakat dari kendala internal maupun kendala eksternal. Dari kendala internal yaitu kendala internal yang di alami oleh pihak LBH APIK Banten dan klien dalam memberikan bantuan hukum kepada masyarakat berikut yaitu dari Sumber daya manusia dan sumber daya keuangan, waktu yang tidak sama dengan klien, kurangnya keterbukaan klien dalam mencerita kronologi kasusnya kepada LBH APIK Banten. dalam hal ini, dalam menanagani kasus klien LBH APIK Banten sendiri sangat kekurang dari SDM dan sumber dana keuangan. Karena saat menanganai kasus klien LBH APIK Banten mengeluarkan uang dari masing-masing pengurus. Dan juga sifat LBH APIK Banten lebih pada kasus 
perempuan dan anak yang mengalami kekerasan. kendala di klienya sendiri sulit dan tidak mau membuka diri untuk menceritakan kronologi kasus yang menimpa klien tersebut. Sedangkan kendala yang dihadapi klien sulitnya bertemu dengan pelaku sehingga tidak menemukan hasil yang diharapkan oleh klien.

Kendala eksternalnya yaitu budaya masyarakat yang masih tidak mau melaporkan diri ke LBH APIK saat ia mengalami kasus kekerasan, Aparat Hukum dan penyidiknya yang suka kurang respons Kendala yang dihadapi oleh klien yang pernah di bantu oleh LBH APIK Banten bahwa kendala eksternal yang di alami masyarakat yaitu tidak bertemunya dengan pelaku dan kurang nyaman saat menceritakan kronologi kasusnya. Karena berkaitan dengan masalah privasi diri sendiri.

\section{Solusi LBH APIK Banten dalam} memberikan bantuan hukum kepada masyarakat.

Adapun solusi yang diberikan untuk menjawab kendala internal dan eksternal dalam memberikan bantuan hukum pada masyarakat yaitu solusinya dengan cara melakukan sosialisai lebih rutin lagi ke masyarakat-masyarakat mengenai (LBH APIK, Bantuan hukum dan mengenai isue perempuan dan anak), dibutuhkan perjuangan lebih ke Aparatur Hukum dalam menangapi masyaraktnya yang membutuhkan bantuan dari APH tersebut. Sedangkan solusi dari masyarakat yang pernah di tangani kasusnya oleh LBH APIK Banten yaitu solusinya lebih pada ke masyarakatnya yaitu untuk masyrakat yang telah mengalami tindakan pelecehan, pencabulan, KDRT, dan lain-lain. memang sulit untuk menceritakan kasus tersebut ke orang lain. tapi bagaimanapun juga harus melaporkan agar kaum perempuan di lindungi dari tindakantindakan tersebut. Untuk masyarakat yang mengalami kasus atau kejadian seperti itu jangan takut untuk melaporkannya pada LBH APIK Banten. dengan melaporkan kasus tersebut ke LBH APIK maka para pelaku nantinya akan jera. Dan tidak semena-mena dengan para perempuan.

\section{KESIMPULAN}

Berdasarkan penelitian dan pembahasan sebelumnya mengenai Peran Lembaga Bantuan Hukum (LBH) Asosiasi Perempuan Indonesia untuk Keadilan (APIK) Banten Dalam Memberikan Perlindungan Hukum Bagi Masyarakat dapat di simpulkan bahwa Undang-Undang Bantuan Hukum Nomor 16 Tahun 2011 Tentang Bantuan Hukum ayat 1 
menyatakan bahwa "Bantuan Hukum yang diselenggarakan oleh negara yang diatur dalam pada Pasal 1 Ayat (1) dan (2) menyatakan, Ayat (1) bantuan hukum adalah jasa hukum yang diberikan oleh pemberi bantuan hukum secara cumacuma kepada penerima bantuan hukum". Adapun Peran LBH APIK Banten Dalam Memberikan Perlindungan Hukum Bagi Masyarakat sangat berperan sekali. dengan adanya LBH APIK Banten ini tentunya sangat membantu masyarakat yang mengalami kasus kekerasan terhadap perempuan yang meliputi KDRT, pencabulan anak di bawah umur, pemekosaan, penganiyayan, dan pelecehan seksual. Peran LBH APIK Bante sudah menjalankan perannya sesuai dengan Undang-Undang bantuan hukum.

\section{DAFTAR PUSTAKA}

Sari, Dian Pramita (2011) Peran Lembaga Bantuan Hukum Semarang Dalam Perjuangan Penegakan Hukum (Studi Kasus Atas Pencurian Kapuk Randu Di Kabupaten Batang. (Skripsi, Universitas Negeri Semarang 2011) diakses pada 01 Desember 2018 pukul 19.39 WIB dari https://lib.unnes.ac.id/2808/1/ 3497.pdf

Sugiyono. (2015). Metodologi Penelitian Kuantitatif, Kualitatif, dan $R \& D$. Bandung: CV Alfabeta.

Sugiyono. (2014). Metode Penelitian Kuantitatif Kualitatif dan $R \& D$. Bandung : Alfabeta.

Undang-Undang Republik Indonesia Nomor 16 Tahun 2011 Tentang Bantuan Hukum. 